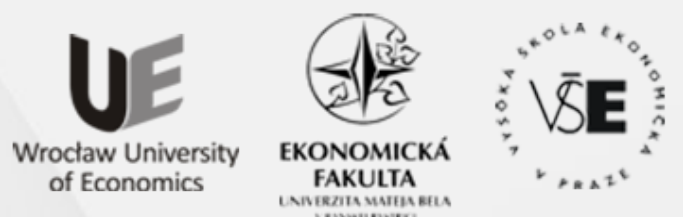

Conference Proceedings

Full TeXT PAPERS

edited by

Zofia Rusnak and Beata Zmyślona

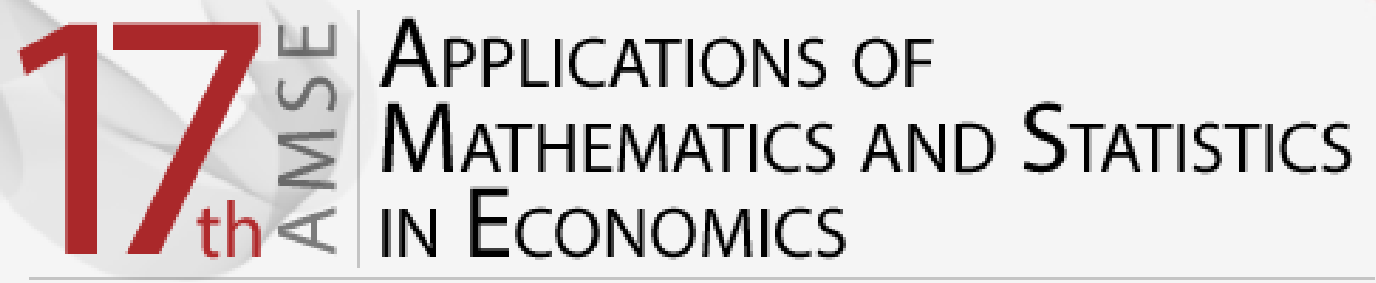

International Scientific Conference | Poland • 27-31 August 2014 
Scientific Committee

Richard Hindls, Stanislava Hronová, Rudolf Zimka, Walenty Ostasiewicz, Emília Zimková, Zofia Rusnak, Martin Bod'a

Organizing Committee

Beata Zmyślona, Cyprian Kozyra, Grzegorz Rogoziński, Kristýna Vltavská

\section{Reviewers}

Milan Bašta, Diana Bílková, Martin Bod'a, Joanna Dębicka, Tomáš Fiala, Jakub Fischer, Stanisław Heilpern, Karel Helman, Lenka Hudrlíková, Miroslav Hužvár, Nikola Kaspř́ková, Alena Kaščáková, Kamil Kladívko, Jindřich Klůfa, Pavol Král', Katarzyna Kuziak, Jana Langhamrová, Ivana Malá, Tomáš Marcinko, Luboš Marek, Miloš Maryška, Petr Mazouch, Zofia Mielecka-Kubień, Witold Miszczak, Petr Musil, Gabriela Nedelová, Walenty Ostasiewicz, Iva Pecáková, Viera Roháčová, Zofia Rusnak, Mária Stachová, Jana Špirková, Šárka Šustová, Jana Tepperová, Vladimír Úradníček, Kristýna Vltavská, Michal Vrabec, Dariusz Wawrzyniak, Henryk Zawadzki, Jaroslav Zbranek, Tomáš Zeithamer, Martin Zelený, Jan Zeman, Rudolf Zimka, Emília Zimková, Pavel Zimmermann, David Žižka

Layout

Martin Bod'a, Beata Zmyślona, Grzegorz Rogoziński

Front page design

Grzegorz Rogoziński

CD cover design

Beata Dębska

Articles published in the form submitted by the authors

All rights reserved. No part of this book may be reproduced in any form or in any means without the prior permission in writing of the Publisher

(C) Copyright by Wrocław University of Economics Wrocław 2014

ISBN 978-83-7695-421-9

Wydawnictwo Uniwersytetu Ekonomicznego we Wrocławiu

53-345 Wrocław, ul. Komandorska 118/120 www.ue.wroc.pl

Sprzedaż książek tel./fax 71 36-80-602

e-mail: econbook@ue.wroc.pl www.ksiegarnia.ue.wroc.pl 


\section{Contents}

Foreword

Diana Bílková: TL-Moments: Analogy of Classical L-Moments

Dagmar Blatná: Application of Robust Regression in the Analysis of Internet Access in European Countries

Martin Bod’a, Mária Kanderová: Rebalancing Issues in Tracking Error Variance Minimization

Martin Bod'a, Viera Roháčová: Application of Six Sigma Ideas to Timing Decisions at Financial Markets

Anton Dekrét, Rudolf Zimka: On the Price Hartwick's Task and Its Inverse in a Dynamic Model of an Economy with Exhaustible Resources

Joanna Dębicka, Agnieszka Marciniuk: Comparison of Reverse Annuity Contract and Reverse Mortgage on the Polish Market.

Petra Dotlačilová, Jitka Langhamrová: The Influence of Mortality Models for the Expected Future Life-time of Older People

Marek Ďurica, Lucia Švábová: Delta and Gamma for Chooser Options.

Vlastimil Farkašovský: New Concept of Pension Funds Performance Evaluation

Albert Gardon: The Normality of Weekly Relative Changes of the Freight Rate in Container Shipping.

Mária Grausová, Miroslav Hužvár, Jana Štrangfeldová: Healthcare Systems Efficiency in the Visegrád Group.

Stanisław Heilpern: Multiple Life Insurance - Pension Calculation

Alena Kaščáková, Gabriela Nedelová: Changes in Slovak Households' Economy

Igor Kollár, Pavol Král', Peter Laco: Methodology for Assessing Website Improvement in Corporate Environment.

Maciej Kostrzewski: Some Method of Detecting the Jump Clustering Phenomenon in Financial Time Series.

Cyprian Kozyra, Beata Zmyślona, Katarzyna Madziarska: Complementary Objective and Subjective Measures of Hospital Services Quality...

Pavol Král', Mária Stachová, Lukáš Sobíšek: Utilization of Repeatedly Measured Financial Ratios in Corporate Financial Distress Prediction in Slovakia

Ivana Malá: The Use of Finite Mixture Model for Describing Differences in Unemployment Duration

Lukáš Malec: Studying Economics and Tourism Industry Relations by Smooth Partial Least Squares Method Depending on Parameter. 
Tomáš Marcinko: Consequences of Assumption Violations Regarding Classical Location Tests.

Edyta Mazurek: The Income Tax Progression Depending on Social Insurance Contribution in Poland.

Petr Musil, Jana Kramulová, Jan Zeman: Regional Consumption Expenditures: An Important Starting Point for Regional Input-output Tables.

Katarzyna Ostasiewicz, Walenty Ostasiewicz: Good Life: From Political to Human Economy

Anna Sączewska-Piotrowska: Analysis of Poverty Transitions in Poland Using Multilevel Discrete-Time Event History Models

Martina Šimková, Petra Švarcová: Disadvantaged University Students in the Czech Republic.

Michal Široký: The Use of Short-term Business Statistics for Quarterly GDP Flash Estimates in the Czech Republic

Zdeněk Šulc, Hana Řezanková: Evaluation of Recent Similarity Measures for Categorical Data.

Lucia Švábová, Marek Ďurica: The Relationship Between the Finite Difference Method and Trinomial Trees

Kristýna Vltavská, Jaroslav Sixta: The Estimation of Final Consumption Expenditures

Lenka Vraná: Business Cycle Analysis: Tracking Turning Points

Janusz Wywiał: On Bayesian Testing in Auditing

Emília Zimková: Window Analysis of Supper-efficiency Change: Case of the Slovak Banking System ....

Beata Zmyślona: Statistical Modelling of the Impact of Diabetes on the Risk of Hospitalization 


\title{
APPLICATION OF ROBUST REGRESSION IN AN ANALYSIS OF THE INTERNET ACCESS IN THE EUROPEAN COUNTRIES
}

\author{
DAGMAR BLATNÁ \\ University of Economics, Prague, Faculty of Statistics and Informatics, Department of Statistics and \\ Probability, W.Churchill sq. 4, 13067 Prague 3, Czech Republic \\ email: blatna@vse.cz
}

\begin{abstract}
Individuals Regularly Using the Internet (IRUI) is one of the indicators of the information society representing the computer literacy of a country's population. The values of this indicator depend on many different economic factors of the general economic background, employment, innovation and research, science and technology. The values of these indicators vary greatly between the European countries and, consequently, the occurrence of outliers can be expected in an IRUI analysis. In such a case, the classical statistical approach - the least squares method may be highly unreliable, robust regression methods constituting an acceptable and useful tool that can be employed for detecting influential observations as well. The aim of this paper is to demonstrate the applicability and advantages of robust regression methods in an analysis of the European countries' actual economic data. The results obtained by using classical linear least squares and robust regression analysis are compared. The economic IRUI analysis, however, was not the main focus of the present paper.
\end{abstract}

Key words: robust regression, $L S$ regression, outliers, leverage points, internet access

DOI: 10.15611/amse.2014.17.02

\section{Introduction}

The main goal of this paper is to demonstrate the applicability and advantages of robust regression methods in an analysis of the European countries' actual economic data. Indicator IRUI (Individuals Regularly Using the Internet) is one of the indicators of the information society representing the computer literacy of a country's population. This Internet access is monitoring by the Digital Agenda for Europe (DAE), one of seven flagships initiatives under Europe 2020, the EU's strategy to deliver smart sustainable and inclusive growth. The DAE aims to reboot Europe's economy and help Europe's citizens and businesses to get the most out of digital technologies. The aim is to deliver sustainable economic and social benefits from a Digital Single market based on fast and ultra fast internet and interoperable applications, with broadband access. The DAE has set three targets related to broadband access, two of which refer to broadband coverage: all homes should have access to broadband of at least a basic quality by 2013, and all homes should have access to high-speed broadband of at least $30 \mathrm{Mbps}$ by 2020. The appropriate level of Internet access of individuals is prerequisite for the fulfillment of these targets. The values of this indicator depend on many different economic factors of the general economic background, employment, education, innovation and research, science and technology. The values of these indicators vary greatly between the European countries and, consequently, the occurrence of outliers can be expected in an Internet access analysis. In such a case, the classical statistical approach - the least squares method (LS) may be highly unreliable, robust regression methods constituting an 


\section{$12 \backsim$ APPLICATIONS OF

acceptable and useful tool that can be employed for detecting influential observations as well. The economic internet usage analysis not being its main objective.

The remainder of the paper is organized as follows. Section 2 gives description of the analyzed variables and data file. In section 3, we introduce a robust method of regression analysis, robust diagnostic tools and model selection criteria. Subsequently results are presented and commented in section 4. A final section summarizes the results obtained.

\section{Analyzed variables and the data set}

The level of the Internet access can be characterized by a few indicators. In our paper, we analyse that of IRUI (Individuals Regularly Using the Internet ${ }^{1}$ ). IRUI is expressed as a percentage of individuals in the 16-74 age group with at least once a week frequency of using the Internet, IRUI being one of the indicators of the information society that represents the computer literacy of a country's population.

The analysis is based on 2010 data of 27 EU countries. All the data as well as indicator definitions have been adopted from the Eurostat database. Different economic indicators have been used as explanatory variables. A complete list of the indicators employed in the analysis is given in the appendix to this paper, calculations being performed by means of SAS 9.2 and S-Plus 6.2statistical software.

\section{Methodology}

\subsection{Robust regression}

The aim of a regression analysis is to find a good estimate of unknown regression coefficients from the observed data. The usual estimator of regression coefficients comes from the method of ordinary least squares, LS being an optimal regression estimator under the sets of assumptions on the distribution of the error term (normality, homoskedasticity, independence of the errors) and predicted variables.

Robust regression provides an alternative to LS regression that works with less restrictive assumptions. The primary purpose of a robust regression technique is to fit a model that describes information in the majority of the data. In particular, it provides much better regression coefficient estimates when outliers are present in the data. Outliers violate the assumption of normally distributed residuals in LS regression.

It is a common practice to distinguish between two types of outlying observations in regression analysis, those in the response variable representing model failure. Such observations are called outliers in the $y$-direction or vertical outliers, those with respect to the predictors being labeled as leverage points. The leverage point is defined as $\left(x_{k_{1}}, \ldots, x_{k_{p}}, y_{k}\right)$, for which $\left(x_{k_{1}}, \ldots, x_{k_{p}}\right)$ is outlying with respect to $\left(x_{i_{1}}, \ldots, x_{i_{p}}\right)$ in the data set. Outliers that bias the parameter estimates are called bad leverage points, whereas outliers lying along the predicted model are called good leverage points. Regression outliers (influential points) are the cases for which $\left(x_{k_{1}}, \ldots, x_{k_{p}}, y_{k}\right)$ deviates from the linear relation followed by the majority of the data, both the explanatory and response variable being taken into account simultaneously.

In the analysis, LS, LTS, MM and RWLS regression methods have been applied.

\footnotetext{
1 "Regular use" means at least once a week (i.e. every day or almost every day or at least once a week)
} 
First, let us briefly mention the principles of the selected robust methods. Two regression methods were employed. The least trimmed squares (LTS) estimator (proposed by Rousseeuw (1984)) is obtained by minimizing $\sum_{i=1}^{h} r_{(i)}^{2}$, where $r_{(i)}^{2}$ is the $i$-th order statistic among the squared residuals written in the ascending order, $h$ is the largest integer between $[n / 2]+1$ and $([n / 2]+[(p+1) / 2]), p$ is the number of predictors (including an intercept) and $n$ is the number of observations. The usual choice $h \approx 0.75 n$ yields the breakdown point of $25 \%$; (see Hubert, Rousseeuw, van Aelst (2008).

LTS regression with a high breakdown point is a reliable data analytic tool thatcan be used to detect vertical outliers, leverage and influential points (observations whose inclusion or exclusion result in substantial changes in the fitted model) in both simple and multivariate settings. A more detailed description is available in, e.g., Ruppert, Carroll (1980), Rousseeuw (2003), Chen (2002), or Hubert, Rousseeuw, Van Aelst (2008).

MM-estimates (proposed by Yohai (1987) combine a high breakdown point with good efficiency (approximately 95\% to LS under the Gauss-Markov assumption). MM regression is defined by a three-stage procedure (for details, see Yohai (1987), Chen (2002) or Rousseeuw (2003)). At the first stage, an initial regression estimate is computed; it is consistent, robust, with a high breakdown point but not necessarily efficient. In our analysis, two methods of initial estimates are used (LTS and S regression). At the second stage, an M-estimate of the error scale is computed, using residuals based on the initial estimate. Finally, at the third stage, an M-estimate of regression parameters based on a proper redescending $\psi$-function. A more detailed description of robust regression methods is available in Chen (2002), Rousseeuw (2003), Yohai (1987), SAS and SPLUS manuals. Tukey's bisquare loss function was employed.

Reweighted least squares (RWLS) regression minimizes the sum of squared residuals multiplied by the weights $w_{i}$, which are determined from the LTS solution. The effect of the weight staking just the values of 0 or 1 is the same as in the cases for which $w_{i}$ equals zero that are deleted. Therefore, RWLS can be seen as ordinary LS on a "reduced" data set consisting of only those observations that received non-zero weights.

\subsection{Identification of outliers, leverage and influential points}

The following numerical and graphic diagnostics for detecting vertical outliers, leverage points and influential observations have been applied (more in detail see, e.g., Rousseeuw (1984), Rousseeuw, van Zomeren (1990), Rousseeuw (2003), Olive (2002), Chen (2002)):

- Residuals associated with LTS regression,

- Standardized residuals (the residuals divided by the estimates of their standard errors, the mean equaling 0 and standard deviation 1 ).

- Studentized residuals (a type of standardized residuals follows at $\mathrm{t}$-distribution with n-p-2 Df). Attention should be paid to studentized residuals that exceed \pm 2.5 (or \pm 2.0 ).

- The robust distance (Mahalanobis distance)

- Diagnostic plots are provided as fundamental data mining graphical tools that quickly identify outliers and determine whether they have an impact on classical estimates. To visualize vertical outliers and leverage points, the following tools were used: a regression diagnostic plot (that of the standardized residuals of robust regression vs. robust distances $\left.\mathrm{RD}\left(\mathrm{x}_{\mathrm{i}},\right)\right)$, the standardized residuals plot vs. their index, a Normal Q-Q plot of the standardized residuals and a plot of kernel estimates of the residuals' density. 


\subsection{Model selection methods}

In the case of classical LS regression - the classical R-squared, the results of significance ( $t$ and F) tests as well as the diagnostics of residuals' normality are applied. As for robust regression, the decision which of the candidate models is to be preferred is based on the following robust diagnostic selection criteria: robust index of determination, robust deviance, significance robust tests (robust t-test, robust F-tests, robust Wald test), Robust Akaike's Information Criterion (AICR), Robust Bayesian information criterion (BICR) and Robust Final Prediction Error (RFPE); the above criteria are dealt with in, e.g., Chen (2002b), Ronchetti (1985), Hampel, Ronchetti, Rousseeuw, Stahel (1996) or SAS and S-Plus manuals.

\section{Results and discussion}

Due to an enormous output of our analysis, it was impossible to present all tables and graphs. For the IRUI dependent variable, only two models distinguished from the statistical point of view are presented. For each model - fitting results, a numerically robust diagnostic of outliers and leverage points, graphic identification of outliers (a diagnostic graph), goodness-of-fit robust tests and a plot of kernel estimates of residuals' density are presented.

The first model includes explanatory variables Comparative price level (CPL) and Persons with upper secondary or tertiary education attainment (PUSE). Both LS and robust diagnostics identified five leverage points, none of them, however, being also a vertical outlier). Numerical robust diagnostic is shown in Table 1.

Table 1 Robust diagnostics (IRUI CPL+ PUSE model)

\begin{tabular}{|c|c|c|c|c|c|}
\hline Observation & $\begin{array}{c}\text { Mahalanobis } \\
\text { distance }\end{array}$ & $\begin{array}{c}\text { Robust MCD } \\
\text { distance }\end{array}$ & Leverage & $\begin{array}{c}\text { Stand. robust } \\
\text { residual }\end{array}$ & Outlier \\
\hline 8 Greece & 0.7417 & 2.9253 & $*$ & -2.3937 & \\
\hline 9 Spain & 1.3499 & 4.4792 & $*$ & -0.096 & \\
\hline 11 Italy & 1.2279 & 3.9351 & $*$ & -1.7993 & \\
\hline 17 Malta & 2.9831 & 8.7156 & $*$ & 1.8825 & \\
\hline 21 Portugal & 2.6809 & 8.0036 & $*$ & -0.1308 & \\
\hline
\end{tabular}

Source: the author

In such a case, regression parameters both of LS and robust models are similar to each other. All models are presented in Table 2, the model fitting results being shown in Table 3. Because of the absence of vertical outliers, we can consider the LS model fully appropriate. Both the explanatory variables have a positive influence on IRUI, partial regression coefficients being statistically significant at a 3\% level at least (see Table 3).

Table 2 LS and robust regression fits (IRUI CPL+ PUSE model)

\begin{tabular}{|l|l|l|}
\hline Model & Regression fit & R-sq \\
\hline LS & $-6.6367+0.4742 \mathrm{CPL}+0.3708$ PUSE & 0.6003 \\
\hline MM/S & $-6.0208+0.4746 \mathrm{CPL}+0.3642$ PUSE & 0.5424 \\
\hline MM/LTS & $-10.8565+0.4877 \mathrm{CPL}+0.4121$ PUSE & 0.5258 \\
\hline RWLS & $-6.6367+0.4741 \mathrm{CPL}+0.3708$ PUSE & \\
\hline LTS & $-8.8214+0.5022 \mathrm{CPL}+0.4008$ PUSE & 0.7722 \\
\hline
\end{tabular}

Source: the author 


\section{APPLICATIONS OF \\ Mathematics and Statistics \\ IN ECONOMICS \\ International Scientific Conference | Poland • 27-31 August 2014}

Table 3 Model IRUI CPL+ PUSE fitting results

\begin{tabular}{|l|c|c|c|l|c|c|c|}
\hline Method & Parameter & $\begin{array}{c}\text { Value of } \\
\text { regr.coeff. }\end{array}$ & $\begin{array}{l}\text { Standard } \\
\text { error }\end{array}$ & t-value & $\begin{array}{l}\text { Pr( }>\mathrm{t} \mid) \\
(\mathrm{p} \text {-value })\end{array}$ & $\begin{array}{l}\text { Wald test } \\
\text { (Chi-sq) }\end{array}$ & $\begin{array}{l}\mathrm{P}(>\text { Chi) } \\
(\mathrm{p} \text {-value })\end{array}$ \\
\hline LS & Intercept & -6.6367 & 13.0501 & -0.5081 & 0.6157 & & \\
\hline MM/LTS & Intercept & -10.8565 & 15.0193 & & & 0.52 & 0.4698 \\
\hline MM/S & Intercept & -6.0208 & 16.6794 & -0.3610 & 0.7213 & & \\
\hline RWLS & Intercept & -6.6367 & 13.0501 & & & 0.26 & 0.6111 \\
\hline LS & CPL & 0.4742 & 0.0852 & 5.565 & 0.0000 & & \\
\hline MM/LTS & CPL & 0.4877 & 0.0912 & & & 28.63 & 0.0001 \\
\hline MM/S & CPL & 0.4746 & 0.1080 & 4.3953 & 0.0002 & & \\
\hline RWLS & CPL & 0.4742 & 0.0852 & & & 30.97 & 0.0001 \\
\hline LS & PUSE & 0.3708 & 0.1228 & 3.0185 & 0.0059 & & \\
\hline MM/LTS & PUSE & 0.4121 & 0.1419 & & & 8.44 & 0.0037 \\
\hline MM/S & PUSE & 0.3642 & 0.1572 & 2.3169 & 0.0294 & & \\
\hline RWLS & PUSE & 0.3708 & 0.1228 & & & 9.11 & 0.0025 \\
\hline
\end{tabular}

Source: the author

In the second model with four exploratory variables GERD (Gross domestic expenditure on R\&D), TEA (Tertiary educational attainment), HICP (Harmonized Indices of Consumer Prices) and HBA (Households with broadband access), robust diagnostics reveal four vertical outliers (15 Luxembourg, 18 the Netherlands, 24 Slovakia and 27 the United Kingdom) and thirteen leverage points (see Table 4). One observation (18 the Netherlands) is a vertical outlier and leverage point simultaneously. This observation is thus identified as an influential point. Classical diagnostics reveal only leverage points, no vertical outliers (see Figure 1). In such a case, differences between classical and robust models are anticipated. For both LS and robust regression fitting models, see Table 5.

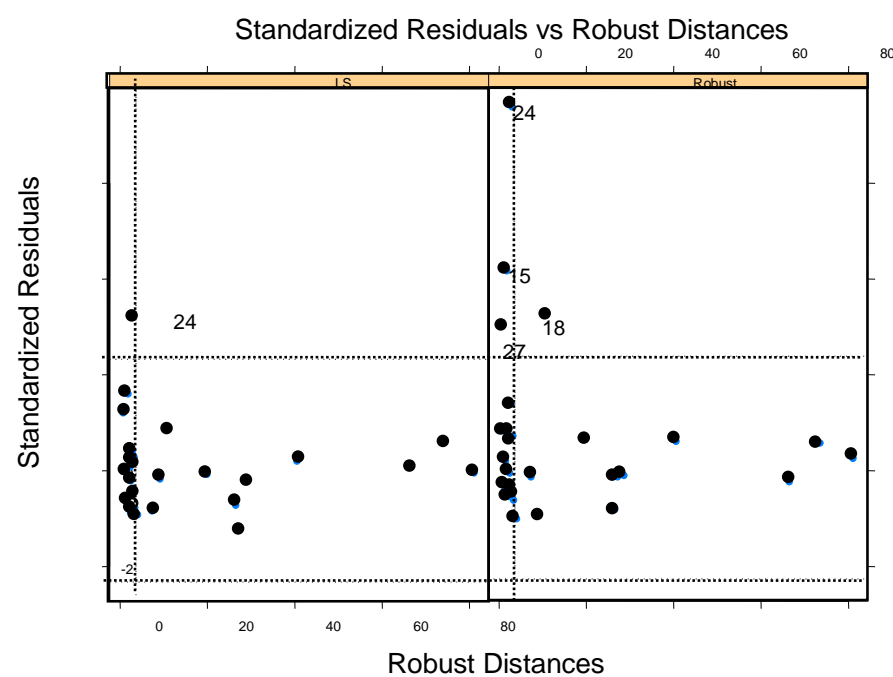

Figure 2 Diagnostic Plot ( IRUI GERD + TEA + HICP + HBA model) Source: the author 


\section{APPLICATIONS OF \\ Mathematics and Statistics \\ IN ECONOMICS}

International Scientific Conference | Poland • 27-31 August 2014

Table 4 Robust diagnostics (IRUI GERD + TEA + HICP + HBA model)

\begin{tabular}{|c|c|c|c|c|c|}
\hline Observation & $\begin{array}{c}\text { Mahalanobis } \\
\text { distance }\end{array}$ & $\begin{array}{l}\text { Robust MCD } \\
\text { distance }\end{array}$ & Leverage & $\begin{array}{l}\text { Stand. robust } \\
\text { residual }\end{array}$ & Outlier \\
\hline 2 Bulgaria & 2.7368 & 15.1077 & $*$ & 0.7759 & \\
\hline 5 Germany & 1.8445 & 2.5091 & * & -0.5125 & \\
\hline 6 Estonia & 1.7464 & 7.4710 & * & -0.1618 & \\
\hline 7 Ireland & 2.5680 & 4.7208 & * & 1.7335 & \\
\hline 8 Greece & 1.5037 & 3.7754 & * & -0.5506 & \\
\hline 13 Latvia & 2.7659 & 12.5959 & * & 0.0044 & \\
\hline 14 Lithuania & 1.9750 & 8.0509 & * & -0.8913 & \\
\hline 15 Luxembourg & 1.3512 & 1.7339 & & 5.8299 & $*$ \\
\hline 16 Hungary & 1.7746 & 9.1245 & $*$ & 0.5271 & \\
\hline 17 Malta & 3.1495 & 7.6023 & * & -0.4367 & \\
\hline 18 Netherlands & 1.8884 & 5.5402 & * & 4.4749 & $*$ \\
\hline 22 Romania & 2.7565 & 14.2269 & * & -0.4465 & \\
\hline 23 Slovenia & 0.6481 & 2.5752 & * & -0.5498 & \\
\hline 24 Slovakia & 1.8057 & 2.0969 & & 10.0342 & $*$ \\
\hline 25 Finland & 2.6515 & 4.162 & $*$ & -0.8605 & \\
\hline 27 United Kingdom & 0.8343 & 1.3322 & & 4.3653 & $*$ \\
\hline
\end{tabular}

Source: the author

As you can see from Tables 5 and 6, all exploratory variables have a positive influence on IRUI. Two regression parameters of the LS model are not significant. Multimodality of the kernel estimate of residuals' density plot (see Figure 2) confirms the presence of an influential point. The kernel estimate of residuals' density of LS fit is bias (it is not centered around zero). Owing to the detected influential point and non-normality of LS residuals' density, the robust model will be given preference. Goodness-of-fit tests for the robust MM model are presented in Table 7.

Table 5 Models fitting results ((IRUI GERD + TEA + HICP + HBA)

\begin{tabular}{|l|c|c|c|c|c|c|c|}
\hline \multicolumn{1}{|c|}{ Method } & Parameter & $\begin{array}{c}\text { Value of } \\
\text { regr.coeff. }\end{array}$ & $\begin{array}{c}\text { Standard } \\
\text { error }\end{array}$ & $\mathrm{t}$-value & $\begin{array}{c}\operatorname{Pr}(>\mid \mathrm{t}) \\
(\mathrm{p} \text {-value })\end{array}$ & $\begin{array}{c}\text { Wald test } \\
(\text { Chi-sq })\end{array}$ & $\begin{array}{c}\mathrm{P}(>\text { Chi) } \\
(\mathrm{p} \text {-value })\end{array}$ \\
\hline LS & Intercept & -23.7976 & 25.8689 & -0.9159 & 0.3676 & & \\
\hline MM/LTS & intercept & -45.7121 & 15.9947 & & & 8.19 & 0.0043 \\
\hline MM/S & intercept & -43.8249 & 11.6330 & -3.7673 & 0.0011 & & \\
\hline LS & GERD & 2.0617 & 2.1476 & 0.9600 & 0.3475 & & \\
\hline MM/LTS & GERD & 4.4500 & 1.3577 & & & 14.74 & 0.0010 \\
\hline MM/S & GERD & 5.3701 & 1.0086 & 5.3241 & 0.0000 & & \\
\hline LS & TEA & 0.1414 & 0.1593 & 0.8875 & 0.3844 & & \\
\hline MM/LTS & TEA & 0.1996 & 0.0988 & & & 4.08 & 0.0434 \\
\hline MM/S & TEA & 0.1706 & 0.0721 & 2.3676 & 0.0271 & & \\
\hline LS & HICP & 0.2481 & 0.1836 & 1.3510 & 0.1904 & & \\
\hline MM/LTS & HICP & 0.4064 & 0.1126 & & & 13.02 & 0.0003 \\
\hline MM/S & HICP & 0.4160 & 0.0820 & 5.0732 & 0.0000 & & \\
\hline LS & HBA & 0.8712 & 0.1654 & 5.2668 & 0.0000 & & \\
\hline MM/LTS & HBA & 0.8031 & 0.1020 & & & 61.98 & 0.0000 \\
\hline MM/S & HBA & 0.7325 & 0.0768 & 9.5428 & 0.0000 & & \\
\hline
\end{tabular}

Source: the author 


\section{APPLICATIONS OF \\ Mathematics AND Statistics \\ IN ECONOMICS \\ International Scientific Conference | Poland • 27-31 August 2014}

Table 6 LS and robust regression fits (IRUI GERD + TEA + HICP + HBA)

\begin{tabular}{|l|c|c|}
\hline \multicolumn{1}{|c|}{ Model } & Regression fit & R-sq \\
\hline LS & $-23.7976+2.0617$ GERD +0.1414 TEA $+0.2481 \mathrm{HICP}+0.8712 \mathrm{HBA}$ & 0.8324 \\
\hline MM/LTS & $-45.7121+4.4500 \mathrm{GERD}+0.1996 \mathrm{TEA}+0.4064 \mathrm{HICP}+0.8031 \mathrm{HBA}$ & 0.7426 \\
\hline MM/S & $-43.8249+5.3701 \mathrm{GERD}+0.1706 \mathrm{TEA}+0.4160 \mathrm{HICP}+0.7325 \mathrm{HBA}$ & 0.7084 \\
\hline RWLS & $-45.8790+4.1428 \mathrm{GERD}+0.1989 \mathrm{TEA}+0.3998 \mathrm{HICP}+0.8319 \mathrm{HBA}$ & - \\
\hline LTS & $-52.1931+5.3082 \mathrm{GERD}+0.1000 \mathrm{TEA}+0.4825 \mathrm{HICP}+0.7779 \mathrm{HBA}$ & 0.9706 \\
\hline
\end{tabular}

Source: the author

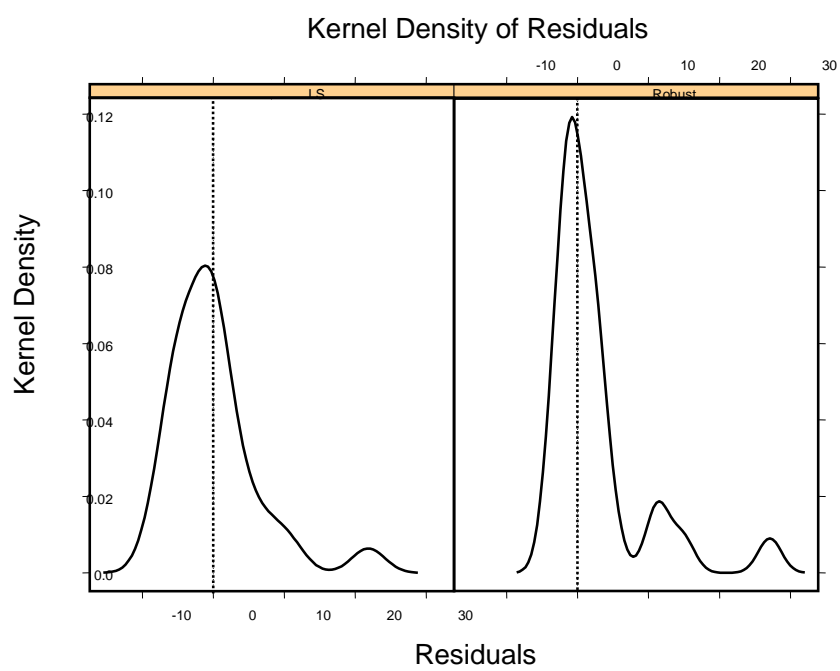

Figure 2 Kernel estimate of residuals' density (IRUI GERD +TEA+HICP+HBA model) Source: the author

Table 7 Goodness-of-fit tests for robust MM model

\begin{tabular}{|l|c|c|c|c|c|}
\hline \multicolumn{1}{|c|}{ Outliers } & R-sq. & AICR & BICR & Deviation & RFPE \\
\hline $\begin{array}{l}\text { Leverage points } \\
\begin{array}{l}2,5,6,7,8,12,13,14,16,17,18,22,23,25 \\
\text { Vertical outliers } \\
15,18,24,27\end{array}\end{array}$ & 0.7426 & 20.979 & 34.005 & 439.10 & 18.022 \\
\hline
\end{tabular}

Source: the author

\section{Conclusion}

The level of the Internet access can be characterized by a few indicators. IRUI (Individuals Regularly Using the Internet) is expressed as a percentage of individuals in the 16-74 age group with at least once a week frequency of using the Internet, IRUI being one of the indicators of the information society representing the computer literacy of a country's population. The adequate level of Internet access of individuals is prerequisite for the fulfillment of the objectives set out in the Digital Agenda for Europe, which is one of seven flagships initiatives under Europe 2020, the EU's strategy to deliver smart sustainable and inclusive growth. The values of IRUI depend on many different economic factors of the 


\section{$12 \backsim$ APPLICATIONS OF

general economic background, employment, education, innovation and research, science and technology. Two distinguished models from a statistical point of view were presented.

In an analysis of real economic data, vertical outliers, leverage points and influential points are supposed to occur. In such a case, the application of the least square regression (LS) could lead to incorrect results, robust regression methods being a useful analytical tool. Robust regression with a high breakdown point (LTS) can detect influential points as well.

Robust techniques provide the results similar to LS regression when the data are linear with normally distributed errors. When vertical outliers are not identified in the data, errors being normally distributed, LS regression is a fully appropriate method and should be preferred. This conclusion is demonstrated by the model with exploratory variables Comparative price level (CPL) and Persons with upper secondary or tertiary education attainment. Both the explanatory variables have a positive influence on IRUI (see IRUI CPL+ PUSE model).

However, regression coefficient estimates can differ markedly when the data contain significant vertical outliers and influential points. In such cases, robust regression techniques should be preferred. It is evident that an improper use of the classical least square regression model with significant variables without the corresponding identification of outliers and assessment of residual normality can lead to the acceptance of incorrect LS models. This conclusion is observed in the model with exploratory variables Gross domestic expenditure on R\&D, Tertiary educational attainment, Harmonized Indices of Consumer Prices and Households with broadband access. All explanatory variables have a positive impact on IRUI (see IRUI GERD + TEA+HICPA+HBA model).

The economic IRUI analysis, however, was not the main focus of the present paper.

\section{Acknowledgements}

The support of the grant Internal Grant Agency of the University of Economics, Prague (VŠE IGA 128/2014) "CONSEQUENCES OF ASSUMPTION VIOLATIONS OF CLASSICAL STATISTICAL METHODS AND THE POSSIBLE USE OF ALTERNATIVE STATISTICAL TECHNIQUES IN ECONOMIC APPLICATIONS" is gladly acknowledged.

\section{References}

1. CHEN,C. 2002 Robust Regression and Outlier Detection with the ROBUSTREG procedure. SUGI Paper, SAS Institute Inc., Cary, NC.,2002 http://www2.sas.com/proceedings/sugi27/p265-27.pdf

2. EUROPEAN COMMISSION Documents and Working papers (2000-2014)

3. HAMPEL, F.R., RONCHETTI, E. M., ROUSSEEUW, P. J., STAHEL, W. A. 1996. Robust Statistics. The Approach Based on Influence Functions. New York: J. Willey, 1986.

4. HUBERT, M., ROUSSEEUW, P.J., VAN AELST. 2008. High-Breakdown Robust Multivariate Methods. Statistical Science 2008, 23 (1), pp.92-119.

5. OLIVE, D.J. 2002. Applications of robust distances for regression. Technometrics.2002, 44(1), pp.64-71.

6. RONCHETTI, E. 1985, Robust Model Selection in Regression, Statistics \& Probability Letters, 2008,3, pp.21-23. 


\section{A \\ Mathematics and Statistics \\ IN ECONOMICS}

International Scientific Conference | Poland • 27-31 August 2014

7. ROUSSEEUW, P.J. 1984. Least median of squares regression. Journal of the American Statistical Association ,1984. 79(388), pp.871 -880.

8. ROUSSEEUW, P. J., LEROY, A. M. 2003. Robust Regression and Outlier Detection. NewJersey: J.Willey.2003.

9. ROUSSEEUW, P.J., VAN ZOMEREN, B.C.1990. Unmasking multivariate outliers and leverage points. Journal of the American Statistical Association,1990, 85(411), pp.633-639.

10. RUPPERT,D., CARROLL, R.J. 1990. Trimmed Least Squares Estimation in the Linear Model. Journal of the American Statistical Association, 1990, 75, pp.828-838.

11. SAS 9.2. Help and documentation.

12. SOMMER, S., HUGGINS, R. M. 1996. Variable Selection Using the Wald Test and a Robust Cp, Applied Statistics, 45, 1996, pp.15-29.

13. S-PLUS 6 Robust Library User's Guide. 2002 Insightful Corporation, Seatle, Washington. 2002

14. YOHAI, V.J. 1987. High breakdown-point and high efficiency robust estimates for regression. The Annals of Statistics, 1987, 15(20), pp.642-656.

15. ZAMAN, A., ROUSSEEUW, P.J., ORHAN, M. 2000. Econometric applications of high-breakdown robust regression techniques. Economics Letters, Vol. 71,2000, pp.1-8.

\section{List of indicators}

$\begin{array}{ll}\text { CPL } & \text { Comparative Price Level (\% of GDP) } \\ \text { ELE } & \text { Early leavers from education and training (\%) } \\ \text { ER } & \text { Employment rate (\%), age group 20-64 } \\ \text { GERD } & \text { Gross domestic expenditure on R\&D (\% of GDP) } \\ \text { GDPc } & \text { GDP per capita in Purchasing Power Standards (PPS) } \\ \text { GDP.gr } & \text { Gross Domestic Product (growth) } \\ \text { HBA } & \text { Households with broadband access (\%) } \\ \text { HICP } & \text { Harmonized Indices of Consumer Prices - Annual average rate of change (\%) } \\ \text { HRST } & \text { Human Resources in Science and Technology (\%) } \\ \text { ILCS } & \text { Individuals' level of computer skills (\%) } \\ \text { LLL } & \text { Participation in education and training (\%) } \\ \text { LPH } & \text { Labour productivity per hour worked } \\ \text { LPP } & \text { Labour productivity per person employed } \\ \text { LTU } & \text { Long-term unemployment (Annual average, in \% of active population); } \\ \text { NNI } & \text { Net national income (\% of GDP } \\ \text { PUSE } & \text { Persons with upper secondary or tertiary education attainment (\%), 25-64 years } \\ \text { RULC } & \text { Real unit labour cost growth - Percentage change on previous period } \\ \text { TEA } & \text { Tertiary educational attainment (\%)r, age group 30-34 }\end{array}$

